\title{
Non-benzoquinone geldanamycin analogs trigger various forms of death in human breast cancer cells
}

\author{
Zhirui Zhang ${ }^{1 \dagger}$, Hong-Mei Li ${ }^{1 \dagger}$, Can Zhou' ${ }^{1}$ Qixiang Li ${ }^{1}$, Linyan Ma' ${ }^{1}$ Zixuan Zhang ${ }^{2}$, Yiming Sun ${ }^{1}$, Lirong Wang ${ }^{3}$, \\ Xudong Zhang ${ }^{4}$, Bing Zhu', Young-Soo Hong ${ }^{6}$, Cheng-Zhu Wu ${ }^{1 *}$ and Hao Liü*
}

\begin{abstract}
Background: Hsp90 proteins are important therapeutic targets for many anti-cancer drugs in clinical trials. Geldanamycin (GA) was identified as the first natural inhibitor of Hsp90, increasing evidence suggests that GA was not a good choice for clinical trials. In this study, we investigated two new non-benzoquinone geldanamycin analogs of Hsp90 inhibitors, DHQ3 and 17-demethoxy-reblastatin (17-DR), to explore the molecular mechanisms of their anti-cancer activity in vivo and vitro.

Methods: MTT and colony formation assays were used to measure cell viability. Flow cytometry, DAPI staining, ATP assay, electron microscopy, western blots, siRNAs transfection and immunofluorescence were used to determine the molecular mechanism of DHQ3- or 17-DR-induced different forms of death in human breast cancer MDA-MB-231 cells. Malachite green reagent was used to measure ATPase activity of the analogs.

Results: DHQ3 and 17-DR presented efficiently inhibitory effect in MDA-MB-231 cell lines, and DHQ3 induced necroptosis by activation of the RIP1-RIP3-MLKL necroptosis cascade. And DHQ3-induced cell death was inhibited by a necroptosis inhibitor, necrostatin-1 (Nec-1), but not by a caspase inhibitor z-VAD-fmk. On the other hand, 17-DR induced apoptosis in MDA-MB-231 cells, indicating a caspase-dependent killing mechanism. We further demonstrated that down-regulation of RIP1 and RIP3 by siRNA protected against DHQ3 but not 17-DR induced cell death. These results were confirmed by electron microscopy. DHQ3 and 17-DR induced the degradation of Hsp90 client proteins, and they showed strong antitumor effects in MDA-MB-231 cell-xenografted nude mice.

Conclusions: These findings supported that DHQ3 and 17-DR induce different forms of death in some cancer cell line via activation of different pathways. All of the results provided evidence for its anti-tumorigentic action with low hepatotoxicity in vivo, making them promising anti-breast cancer agents.
\end{abstract}

Keywords: Geldanamycin analogs, Hsp90, Necroptosis, Apoptosis, Breast cancer

\section{Background}

Breast cancer is the most common life-threatening carcinoma, affecting women worldwide. Although considerable progress in treatment development has been made over the past decades, the incidence of breast cancer has been rising sharply in developing countries [1]. Therefore, there is a requirement to develop novel therapeutic agents to treat breast cancer.

\footnotetext{
* Correspondence: wuchengzhu0611@foxmail.com; liuha06886@foxmail.com ${ }^{\dagger}$ Equal contributors

${ }^{1}$ Faculty of Pharmacy, Bengbu Medical College, Bengbu 233000, Anhui,

People's Republic of China

Full list of author information is available at the end of the article
}

Hsp90 and its co-chaperones stabilize various growth factor receptors, signal transduction proteins such as PI3K and AKT, and mutant proteins in cancerous cells [2, 3]. Inhibiting Hsp90 in these cells selectively induces the degradation of over-expressed or mutated proteins, thereby curbing cancer cell growth. Increased expression levels of Hsps are common in human breast cancers, making them potential selective targets [4]. Small molecular Hsp90 inhibitors have been developed and demonstrated promising anti-cancer profiles [5]. Geldanamycin (GA) was identified as the first natural inhibitor of Hsp90. However due to its poor aqueous solubility and its 
toxicity, GA has not been considered in clinical trials $[6,7]$. Therefore, new GA derivatives with improved pharmacological profiles are needed. DHQ3 and 17demethoxy-reblastatin (17-DR), two non-quinone GA analogs, were obtained from a genetically modified strain of Streptomyces hygroscopicus JCM442 and their structures have been determined $[8,9]$. The phenolic structure effectively improved the water solubility as compared to the benzoquinone structure. Their ATPase inhibition activity has been proved, but their anti-tumor proliferative activities remain unclear.
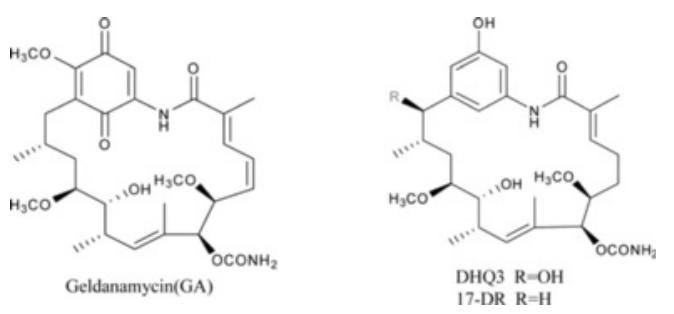

Our previous work showed that the GA analogs could induce cell death in breast cancer cells [10] and human hepatocellular carcinoma cells [11]. Historically, cell death has been classified into distinct forms, including apoptosis, necrosis and autophagy. Caspase activation plays an essential role in the apoptotic process $[12,13]$. In the absence of caspase activation, a regulated cellular necrosis, called necroptosis, prevails [14-16]. In the necroptosis process, receptor-interacting protein (RIP) kinase family works together with death receptor proteins to regulate cell death. Recent studies have revealed that RIP3 kinase functions with RIP1 at the intersections of apoptosis, necroptosis, and cell survival [17]. RIP3 is a key determinant of necroptosis [18], the serine phosphorylation is required for the interaction of RIP3 with its substrate mixed lineage kinase domain-like protein (MLKL) [19]. RIP1 and RIP3 form the 'necrosome' and subsequently phosphorylate MLKL, causing necroptosis in various cell types [20-22]. Emerging evidence suggests that CaMKII [23], Hsp90 and cochaperone $\mathrm{CDC} 37$ [5] are required for RIP3 activation during necroptosis. In addition, necroptosis can be specifically inhibited by necrostain-1 (Nec-1), a small molecule targeting the death domain kinase RIP1 [14].

Herein, we demonstrated that DHQ3 induces necroptosis in MDA-MB-231 cells through effects on the RIP1-RIP3-MLKL cascade, while 17-DR induces caspase-dependent apoptosis. However, these results were not observed in other cancer cell lines. These two new compounds showed highly effective antitumor activity in vitro and in vivo against breast cancer, providing a foundation for targeted breast cancer therapies.

\section{Methods \\ Reagents and antibodies}

DHQ3 and 17-DR were obtained as described previously. They were dissolved in dimethyl sulfoxide (DMSO, Biosharp, Hefei, China) and stored at $-20{ }^{\circ} \mathrm{C}$. MG132, Nec-1, DAPI (4,6-diamidino-2-phenylindole), and 3-(4,5Dimethylthiazol-2-yl)-2,5-diphenyltetrazolium bromide (MTT) were purchased from Sigma-Aldrich (St. Louis, MO, USA). PI assay kits were purchased from Beyotime Institute of Biotechnology (Wuhan, China) and the Annexin V FITC/PI apoptosis detection kit was purchased from Nanjin KeyGen Biotech (Nanjing, China). The ATP Assay kit was purchased from Merck KGaA (Darmstadt, Germany). Lipofectamine 2000 was purchased from Invitrogen (USA). The following antibodies were used: antiMcl-1, anti-PARP, anti-RIP1, anti-RIP3 (Santa Cruz Biotechnology, Santa Cruz, CA, USA); anti-Bcl-2, anti-Bax, anti-HIF1a, anti-CDK4, anti-Her2, anti-EGFR (Proteintech, Chicago, IL, USA); anti-Hsp70, anti-Hsp90, anti-Akt (Cell Signaling Technology, Beverly, Massachusetts, USA); anti-caspase 3 and anti-caspase 8 (ENZO, Switzerland); anti-C-Raf (Abcam, Cambridge, MA, USA); and anti- $\beta$ actin (BioSharp, Hefei, China).

\section{Cell lines and cell culture}

The human breast cancer cell lines MDA-MB-231, MCF-7 and T-47D, human hepatocellular carcinoma (HCC) cell lines HepG2 and SMMC7721, human nasopharyngeal carcinoma cell lines HNE1 and CNE-2Z, human gastric cancer cell line SGC7901, human endometrial cancer cell line ISK, and human non-small cell lung cancer cell line A549 were bought from Shanghai Cell Bank (Shanghai, China). The human colon carcinoma SW480 was obtained from the American Type Culture Collection (Manassas, VA, USA). Cells were obtained, frozen and cultured in our laboratory. The cells were maintained in Dulbecco's modified Eagle's medium (DMEM) (Gibco) or Roswell Park Memorial Institute (RPMI)-1640 medium (Gibco), supplemented with $10 \%$ fetal bovine serum (FBS), $100 \mathrm{U} / \mathrm{mL}$ penicillin, and $100 \mu \mathrm{g} / \mathrm{mL}$ streptomycin. Cells were grown in an atmosphere containing $5 \% \mathrm{CO}_{2}$ at $37{ }^{\circ} \mathrm{C}$.

\section{Cell viability assay}

Cell were plated at a density of $6 \times 10^{3}$ cells/well in a 96well plate for $24 \mathrm{~h}$, and then treated with different concentrations of analogs. At time points, $15 \mu \mathrm{L}$ MTT ( $5 \mathrm{mg} / \mathrm{mL}$ in phosphate-buffered saline, PBS) was added to the wells and the plates were incubated further for $4 \mathrm{~h}$ at $37{ }^{\circ} \mathrm{C}$. Then, the solution was removed and 
replaced with $150 \mu \mathrm{L}$ of DMSO and the absorbance was measured at $490 \mathrm{~nm}$ using a plate reader.

\section{Colony formation assay}

Cells were cultured in 6-well plates (6000 cells/well) overnight. The medium was then exchanged with fresh medium containing DHQ3 or 17-DR. The plates were incubated under cell culture conditions for another 5 days, at which point the medium was removed and the cells were washed twice with PBS and fixed with paraformaldehyde for $10 \mathrm{~min}$ at $-20{ }^{\circ} \mathrm{C}$. The colonies were stained with $2 \%$ crystal violet for $10 \mathrm{~min}$, washed with double-distilled water and dried at room temperature, before being counted.

\section{Flow cytometry}

Cells $\left(1.2 \times 10^{5}\right.$ cells/well $)$ were seeded in 12 -well plates and treated with the analogs. After treatment for $24 \mathrm{~h}$, cells were collected and mixed with $50 \mu \mathrm{g} / \mathrm{mL}$ propidium iodide (PI). Cells permeable to PI were counted by Accuri C6 flow cytometry (BD Biosciences, State of New Jersey, U.S.A). To further analyze cell death, Annexin-V FITC/PI staining was performed on cells treated using the method just described, according to the manufacturer's instructions.

\section{DAPI staining}

Cells were plated in 6-well plates $\left(1.2 \times 10^{5}\right.$ cells/well $)$. Following treatment with DHQ3 or 17-DR for $24 \mathrm{~h}$, the cells were fixed with paraformaldehyde for $10 \mathrm{~min}$ at $4^{\circ}$ $\mathrm{C}$, washed twice with ice-cold PBS and incubated with $100 \mu \mathrm{L}$ of DAPI solution $(2 \mu \mathrm{g} / \mathrm{mL})$ for $5 \mathrm{~min}$ in the dark. After washing three times with PBS, the cells were observed using an IX71 fluorescence microscope (Olympus, Tokyo, Japan). Cells death was characterized by chromatin condensation and nuclear fragmentation.

\section{Measurement of intracellular ATP}

Cells $\left(1.2 \times 10^{5}\right.$ cells/well) were seeded in a 6-well plate for $24 \mathrm{~h}$ prior to incubation with diverse concentrations of analogs for $5 \mathrm{~h}$. To measure intracellular ATP levels, we used a luminometric-based ATP Assay kit according to the manufacturers protocol. The signal was measured by a Luminoskan luminometer (Thermo Scientific, Atlanta, GA, USA). The ATP concentration with each treatment was calculated as a percentage of that of the control.

\section{Evaluation of cell death form by electron microscopy}

Cultured cells were washed and fixed with $2 \%$ paraformaldehyde and $3 \%$ glutaraldehyde in $0.1 \mathrm{M}$ PBS $(\mathrm{pH} 7.4)$ at $4{ }^{\circ} \mathrm{C}$. Then, the cells were post-fixed with $1 \%$ osmium tetroxide for $1.5 \mathrm{~h}$, washed once and treated with $3 \%$ aqueous uranyl acetone, before being dehydrated with a graded series of ethanol and acetone and embedded in Araldite. Thin sections were cut using a Reichert ultramicrotome (Leica, Wetzlar, Germany), post-stained with $0.3 \%$ lead citrate, and examined by TEM (Olympus JEOL, Peabody, MA, USA).

\section{Western blot analysis}

Cells were harvested and homogenized in RIPA lysis buffer for $30 \mathrm{~min}$ on ice, the lysates were centrifuged at $12,000 \times g$ for $30 \mathrm{~min}$ at $4{ }^{\circ} \mathrm{C}$. A bicinchoninic acid (BCA) assay was used to detected protein concentrations. Equal amounts of total protein were separated by sodium dodecyl sulfatepolyacrylamide gel electrophoresis (SDS-PAGE) and transferred to polyvinylidene fluoride (PVDF) membranes. After the membranes were blocked with $5 \%$ skim milk in PBS with $0.1 \%$ Tween 20 for $4 \mathrm{~h}$, they were incubated overnight at $4{ }^{\circ} \mathrm{C}$ with primary antibodies, followed by incubation with the corresponding secondary antibodies. The membranes were imaged with gel imaging equipment (Bio-Rad, USA). $\beta$-actin was used as a loading control.

\section{Immunofluorescence}

Cells in 12-well plates $\left(1.2 \times 10^{5}\right.$ cells/well $)$ were cultured to reach exponential growth prior to being treated with varying concentrations of analogs for $24 \mathrm{~h}$. After treatment, cells were fixed with paraformaldehyde for $15 \mathrm{~min}$, permeabilized for $10 \mathrm{~min}$ in $0.2 \%$ Triton X-100, and incubated for $2 \mathrm{~h}$ in blocking buffer (5\% BSA in PBS). Next, cells were incubated with RIP1 or RIP3 antibody overnight at $4{ }^{\circ} \mathrm{C}$, and visualized with FITCconjugated Goat Anti-Rabbit IgG. The nuclei were stained by incubating cells with $2 \mu \mathrm{g} / \mathrm{mL}$ DAPI in PBS and then washed extensively with PBS. Images were obtained by fluorescence microscopy.

\section{Small interfering RNA transfection}

The RIP1 and RIP3 siRNAs were obtained from GenePharma (China). The siRNA were transiently transfected into MDA-MB-231 cells in 6-well plates using $10 \mu \mathrm{L}$ Lipofectamine 2000 reagent (Invitrogen, USA) according to the manufacturer's protocol. After $48 \mathrm{~h}$ of transfection, the cells were collected for immunoblot analysis as described earlier. The sequences of siRNA used for experiments of human RIP1 siRNA and RIP3 siRNA were as follows: Negative control sense, 5'-UUC UCC GAA CGU GUC ACG UTT-3'and antisense, 5'-ACG UGA CAC GUU CGG AGA ATT-3'; Positive control sense, 5'-UGA CCU CAA CUA CAU GGU UTT-3' and antisense, 5'CUU GAG GCU GUU GUC AUA CTT-3'; RIP1-homo1980 sense, CCUUCUGAGCAGCUUGAUUTT and antisense, AAUCAAGCUGCUCAGAAGGTT; RIP3-homo966 sense, CCGGCUUAGAAGGACUGAATT and antisense, UUCAGUCCUUCUAAGCCGGTT. 


\section{Colorimetric determination of ATPase activity}

The assay was performed as previously described with slight modifications [24, 25]. To prepare the malachite green reagent, and then, either analog or DMSO control was added. The plate was incubated for $2.5 \mathrm{~h}$ at $37{ }^{\circ} \mathrm{C}$. Next, $80 \mu \mathrm{L}$ of malachite green reagent was added to each well, the plate was shaken and $10 \mu \mathrm{L}$ of $34 \%$ sodium citrate was added. The samples were mixed thoroughly for 10-20 min before measuring $\mathrm{OD}_{650}$ using a microplate reader (Synergy HT, BioTek, Vermont, U.S.A).

\section{In vivo experiments}

To evaluate if antitumor effects delivered by DHQ3 and 17-DR, we used the female nude mice (4- to 6-weeks old) to perform experiments, they were obtained from the animal experimental center of Beijing vitalriver. MDA-MB-231 cells $\left(3 \times 10^{6}\right.$ cells per animal $)$ were injected subcutaneously to induce tumor formation. Next, 20 mice that developed tumors over $100 \mathrm{~mm}^{3}$ were randomly divided into five groups ( 5 mice per group), $0.2 \mathrm{ml}$ of DMSO, 17-DR (25 mg/kg), DHQ3 $(50 \mathrm{mg} / \mathrm{kg})$, DDP $(3 \mathrm{mg} / \mathrm{kg})$ were intraperitoneally injected every 3 days, and body weight was monitored before each injection. Tumor volume was measured as length $\mathrm{x}$ width ${ }^{2} / 2$. After treatment 21 days with drugs, the solid tumors were removed and stored in $4 \%$ formalin solution, cut into small pieces that were stained with hematoxylin and eosin (H\&E).

\section{Statistical analysis}

Values are expressed as the means \pm SEM of three experiments. SPSS v.16.0 software (SPSS Inc., Chicago, IL, USA) was used for data analysis. Comparisons between two groups were analyzed using the two-tailed Student's $t$-test. A p-value $<0.05$ is considered statistically significant.

\section{Results \\ Inhibition of MDA-MB-231 cell proliferation with varying concentrations of DHQ3 and 17-DR}

To investigate the effects of DHQ3 and 17-DR on breast cancer cells, MDA-MB-231 cells were treated with different concentrations of DHQ3 and 17-DR for 24, 48 or $72 \mathrm{~h}$. As determined by MTT assays, DHQ3 and 17-DR significantly inhibited MDA-MB-231 cell growth (Fig. 1a and $\mathrm{b})$, the cell viability rates were gradually reduced with the increase of analogs concentration $(p<0.01)$. Furthermore, we observed that DHQ3 and 17-DR could inhibit MDA-MB-231 cells colony formation by increasing concentrations (Fig. 1c).

\section{DHQ3 and 17-DR induce different forms of cell death in MDA-MB-231 cells}

Similarly, MDA-MB-231 cells were treated with DHQ3 or 17-DR for $24 \mathrm{~h}$ and then flow cytometry was used to detect dead cells. As expected, PI-staining indicated an increase in the ratio of dead cells with increasing analog concentrations (Fig. 2a), suggesting that both analogs induce cell death in MDA-MB-231 breast cancer cells. Annexin-V FITC/PI staining gave similar results, with 17DR treatment, we could see a large number of early stage apoptotic cells were in the AV + PI- quadrant (Fig. 2b). With analog treatment, DAPI-stained cells exhibited condensed and fragmented nuclei, which is indicative of cell death (Fig. 2c). Furthermore, it has been debated whether the function of Hsp90 is ATP dependent. It was found that cellular ATP levels were reduced with DHQ3 and 17DR treatment (Fig. 2d), suggesting that the analogs induced cell death by decreasing ATP levels. To further define the types of cell death obtained with analogs treatment, we observed cells under an electron microscope (Fig. 2e). DHQ3 induced typical nuclear fragmentation, loss of plasma membrane integrity, and organelle (especially mitochondrial) swelling. At the same time, cells treated with 17-DR showed typical characteristics of apoptosis: nucleus concentrating, condensation and margination of nuclear chromatin, and nuclear membrane and plasma membrane and organelles intact.

\section{7-DR-induced apoptosis is caspase-dependent}

To verify whether the 17-DR-induced cell death observed in MDA-MB-231 cells was a result of apoptosis, western blot analyses were conducted to measure the levels of apoptosis proteins. Apoptosis was induced in breast cancer cells by 17-DR as confirmed by the downregulation of Mcl-1 and Bcl-2, and up-regulation of Bax protein levels (Fig. 3a). Further, we performed immunoblotting to detect caspase activation. The cleaved products of caspase-3, caspase- 8 and PARP were detected (Fig. 3b), indicating that 17-DR-induced cell death was apoptotic. Furthermore, we pre-treated cells with the necroptosis inhibitor, Nec-1 or the caspase inhibitor, zVAD-fmk. The effects of 17-DR were decreased by treatment with the apoptosis inhibitor z-VAD-fmk (Fig. 3c), the cell viability was $(51.59 \pm 1.27) \%$ when $17-D R$ used alone, increased to $(66.34 \pm 3.25) \%$ in conjunction with z-VAD-fmk $(p<0.01)$, but not by Nec-1 (Fig. 3c and d), indicating a caspase-independent killing mechanism.

\section{Hsp90 inhibitor DHQ3 induces necroptosis in breast cancer MDA-MB-231 cells}

Unlike 17-DR treated cells, cleaved products of caspase-3 and caspase-8 were nearly undetected in DHQ3 treated cells (Fig. 4a). Next, we found that DHQ3 up-regulated expression of RIP1, RIP3 and MLKL (Fig. 4b). In addition, DHQ3 significantly promoted the nuclear translocation of RIP1 and RIP3 (Fig. 4c), they showed DHQ3 increased the expression of RIP1 and RIP3 on the cytoplasm. The viability of DHQ3-treated cells was rescued with Nec-1 pre- 

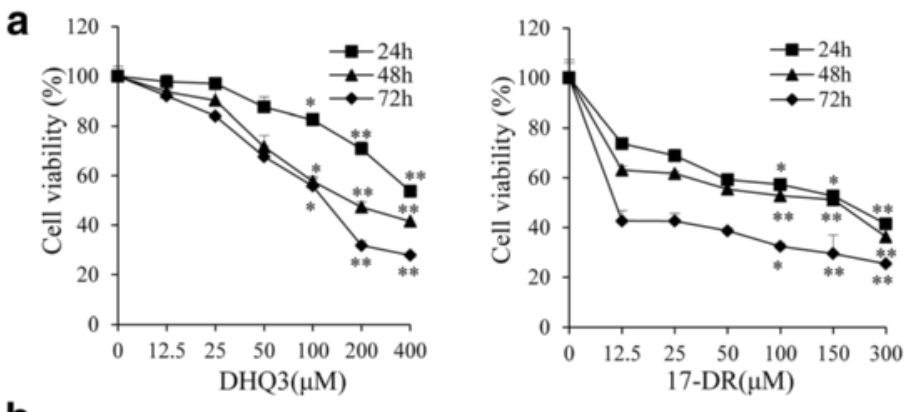

b

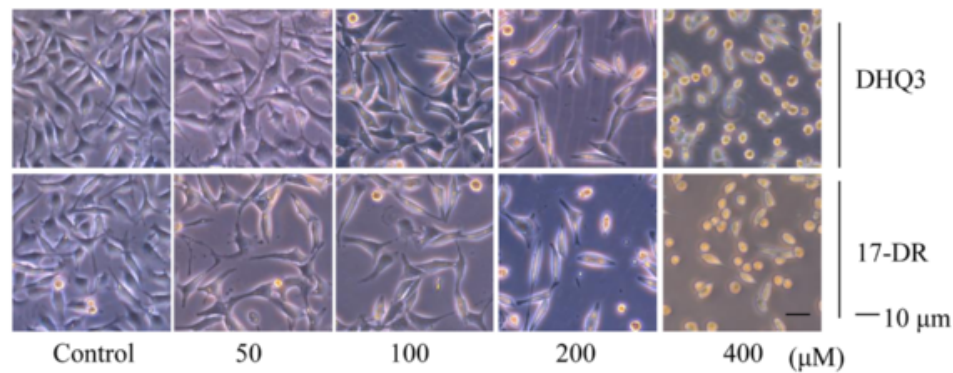

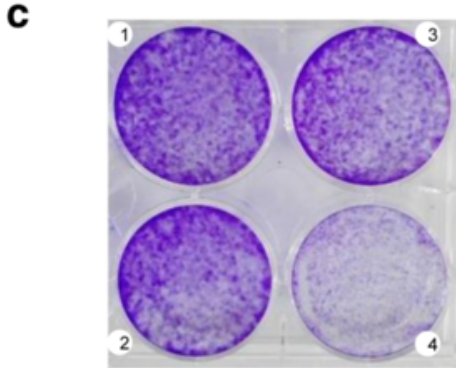

$\operatorname{DHQ} 3(\mu \mathrm{M})$

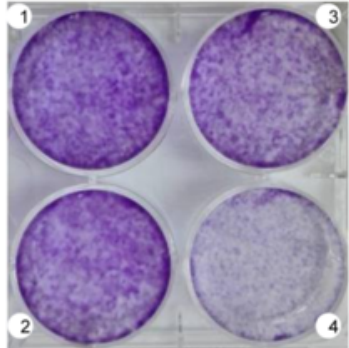

17-DR( $\mu \mathrm{M})$

Fig. 1 Inhibitory effects of DHQ3 and 17-DR on MDA-MB-231 cells. a MDA-MB-231 cells were treated with various concentrations of analogs for 24,48 or $72 \mathrm{~h}$. Cell viability was measured by MTT assay. ${ }^{*} p<0.01,{ }^{* *} p<0.001$. b Cells were treated with analogs for $24 \mathrm{~h}$ and the morphology was examined by light microscopy with differential interference contrast optics. $\mathbf{c}$ The colony-forming capability of MDA-MB-231 cells was measured using a colony formation assay after treatment with various concentrations of analogs for 5 days

treatment (Fig. 4d), there was an increase [(87.39 \pm 0.75$) \%]$ in conjunction with Nec-1 $(p<0.01)$ compared to DHQ3treated alone [(66.32 \pm 0.39$) \%]$. As proven by Annexin-V FITC/PI staining (Fig. 4e), DHQ3/Nec-1 induced less cell death than did DHQ3 alone. Nec-1 significantly protected the cells from DHQ3-induced, reducing right quadrant populations from 31.1 to $18.7 \%$. On the other hand, zVAD-fmk did not protect against DHQ3-induced cell death (Fig. 4d). These results demonstrated that DHQ3 induced necroptosis in breast cancer MDA-MB-231 cells.

\section{Knockdown of RIP with siRNA protected MDA-MB-231 cells against DHQ3-induced necroptosis}

To characterize the mechanisms underlying sensitization to the analogs, we investigated the effect of RIP1 and RIP3 knockdowns on the signaling pathway in MDA-MB-231 cells. Results shown in Fig. 5 demonstrated that silencing RIP1 and RIP3 expression prevented DHQ3 from activating cell death, and caused the loss of Nec-1's protective effect.
However, silencing RIP1 expression (Fig. 5a) did not affect 17-DR-induced cell death, as shown in the MTT and Annexin-V FITC/PI results (Fig. 5b and c). In the normal, the viability was $(87.39 \pm 0.70) \%$ when combined with Nec-1, compared $(65.75 \pm 0.60) \%$ that treated DHQ3 alone; after the silence of RIP1, the viability was $(74.67 \pm 5.61) \%$ in conjunction with Nec-1, compared $(78.42 \pm 3.22)$ \% that treated DHQ3 alone. The same results occurred when RIP3 was silencing (Fig. 5d). The cell viability were $(63.53 \pm 1.44)$ $\%$ and $(72.95 \pm 2.91) \%$ in the before and after processing RIP3 silence when treated DHQ3 alone, and changed to $(85.84 \pm 2.33) \%$ and $(73.94 \pm 4.76) \%$ when combined with Nec-1 (Fig. 5e). Consistent with MTT results, the Annexin-V FITC/PI results approved again, Nec-1 lost its protection for DHQ3 (Fig. 5f). Altogether, these data demonstrated that in MDA-MB231 cells DHQ3 induced necroptosis, which can be mimicked by down-regulation of RIP1 and RIP3. 


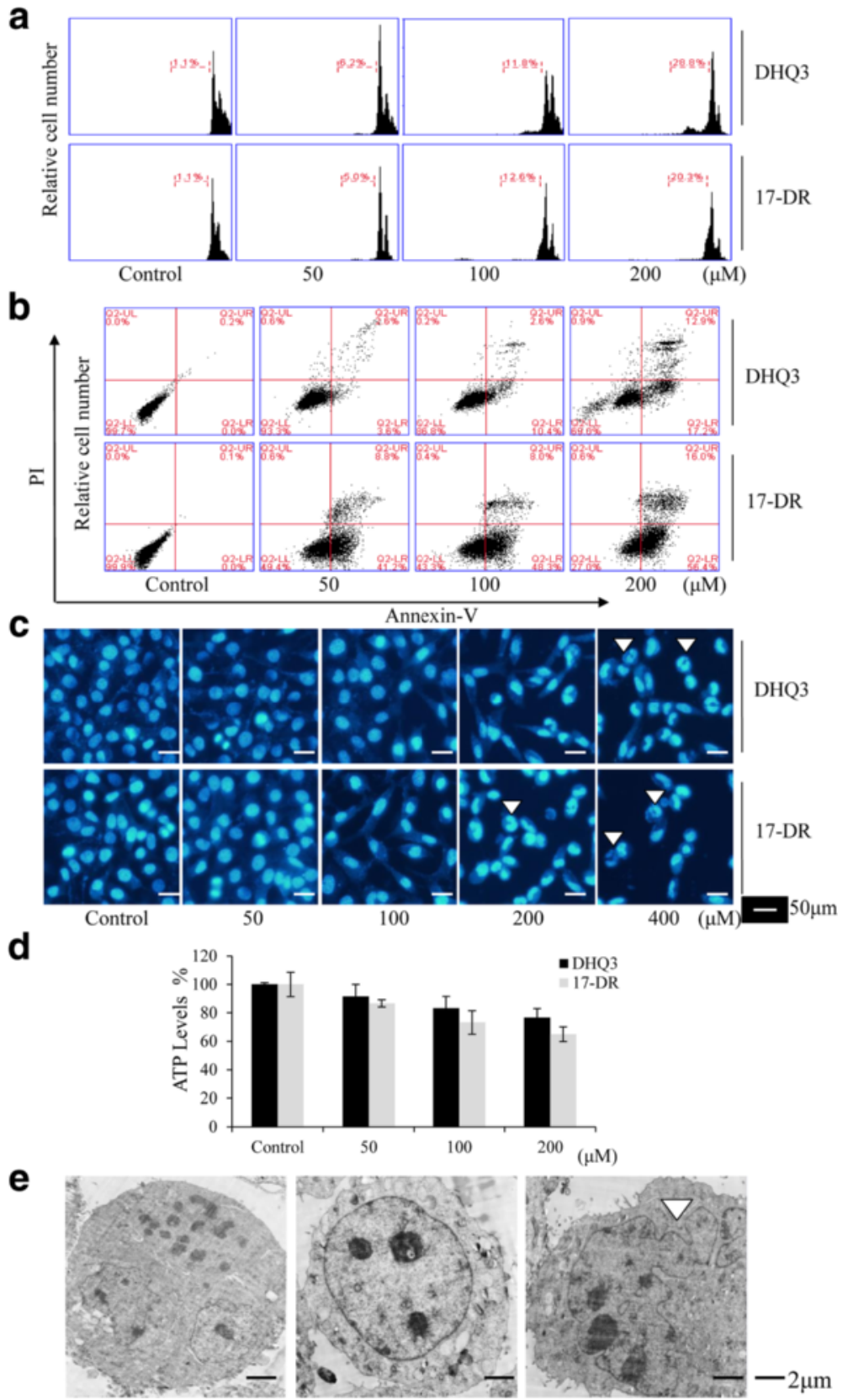

Fig. $2 \mathrm{DHQ3}$ and 17-DR induced various forms of death in MDA-MB-231 breast cancer cells. a Flow cytometric analysis of cell death after treatment with DHQ3 or 17-DR for $24 \mathrm{~h}$ using PI staining. b Cells treated with analogs for $24 \mathrm{~h}$ were analyzed using an Annexin V-FITC/PI assay. c Cells were treated with the indicated concentrations of analogs for $24 \mathrm{~h}$, subjected to DAPI staining (showing nucleus) and visualized by fluorescence microscopy. White arrowheads indicate dead cells. $\mathbf{d}$ Reduction in ATP production after analogs treatment. Cellular levels of ATP were measured after $5 \mathrm{~h}$. e DHQ3 induced necroptosis, while 17-DR induced apoptosis in MDA-MB-231 cells. Electron microscopy of cells treated for $24 \mathrm{~h}$ with DMSO, $200 \mu \mathrm{M}$ DHQ3 or $200 \mu \mathrm{M}$ 17-DR. White arrowheads denote chromatin pyknosis in cells treated with 17-DR

DHQ3 and 17-DR down-regulate Hsp90 client proteins in breast cancer MDA-MB-231 cells

Hsp90 inhibitors have been established as a method of targeting Hsp90 client onco-proteins [26-28] and promoting apoptosis of tumor cells [29]. The isolated analogs were tested for their ability to inhibit yeast Hsp90 activity using the malachite green ATPase assay. Using the optimized reaction conditions, DHQ3 and 17-DR presented stronger ATPase inhibition activity compared to the original Hsp90 inhibitor, GA (Fig. 6a). To confirm the regulation of Hsp90 by DHQ3 and 17-DR, the expression levels of its client proteins were examined, 


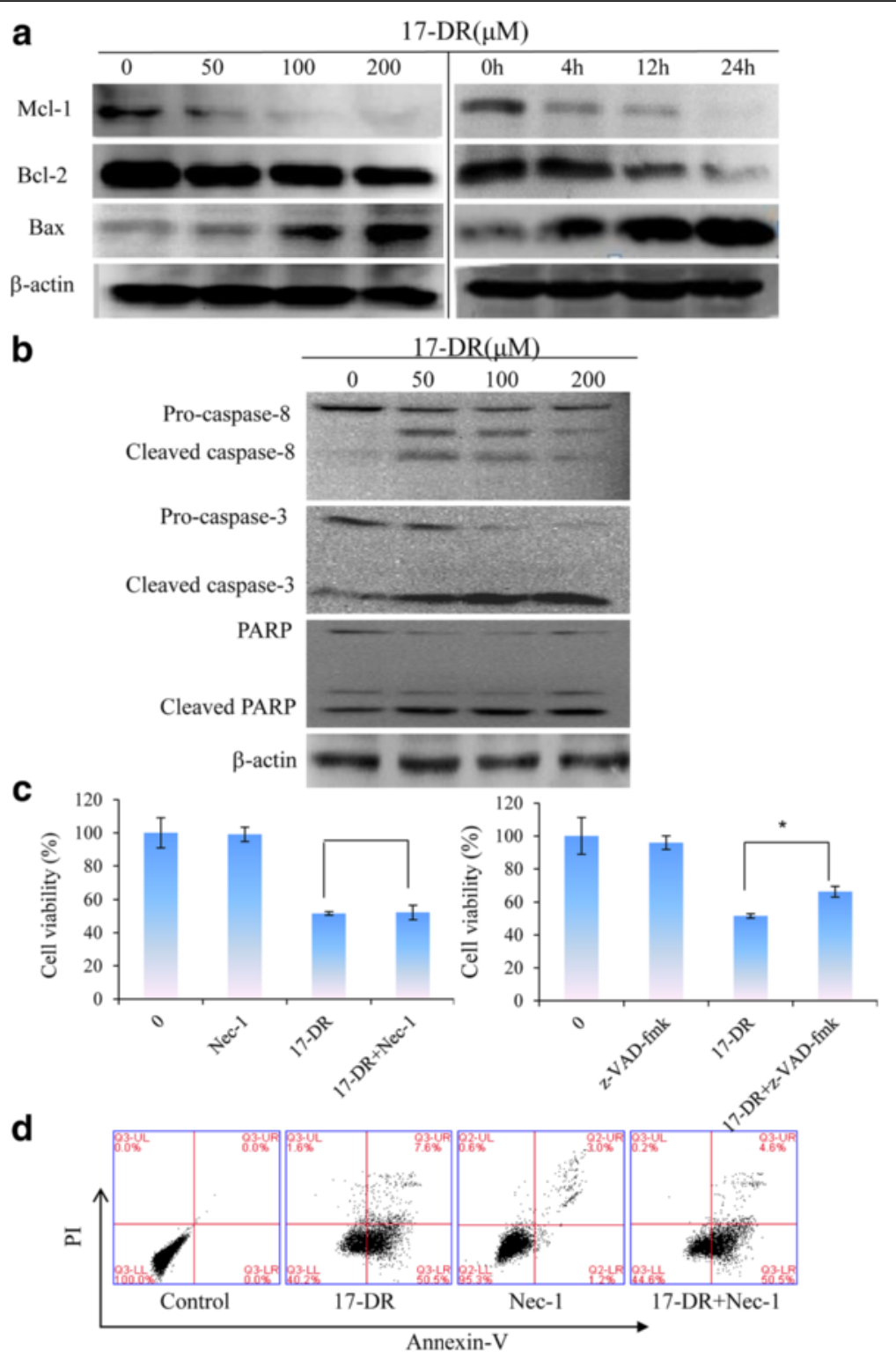

Fig. 3 17-DR induced apoptosis in MDA-MB-231 cells that is dependent of caspase activity. a Whole-cell lysates from the MDA-MB-231 cells treated with different concentrations of 17-DR, or treated with $200 \mu \mathrm{M}$ 17-DR for different lengths of time, were subjected to western blot analysis. $\mathbf{b}$ The expression of caspase-3, -8 and PARP. 17-DR increased their activation at $24 \mathrm{~h}$. c Analysis of cell viability by MTT assay, following treatment with 17-DR with or without $1 \mathrm{~h}$ pre-treatment with Nec-1 or z-VAD-fmk. ${ }^{*} P<0.05 . \mathbf{d}$ Annexin V-FITC/PI analysis following treatment with 17-DR alone or with Nec-1 pre-treatment

including Akt, Her2, CDK4, C-Raf, HIF1 $\alpha$ and EGFR $[3,30]$. Western blot analysis demonstrated that these classical client proteins were significantly downregulated in the presence of DHQ3 and 17-DR (Fig. 6b). Several reports have suggested that the decrease in expression levels of Hsp90 client proteins is due to their degradation by the proteasome. Indeed, a $1 \mathrm{~h}$ pre-treatment with the proteasome inhibitor MG132 was sufficient to partly restore the expression level of client proteins in cells incubated with DHQ3 or 17-DR (Fig. 6c).

\section{In vivo antitumor efficacy of 17-DR or DHQ3}

To test whether 17-DR or DHQ3 show any antitumor effects in vivo, MDA-MB-231 cells were xenografted into nude mice, and then the tumor-bearing animals were treated with $17-\mathrm{DR}(25 \mathrm{mg} / \mathrm{kg} / 3$ days $)$ or DHQ3 (50 $\mathrm{mg} / \mathrm{kg} / 3$ days) for 21 days by intraperitoneal injection. We observed that 17-DR or DHQ3 prevented tumor growth (Fig. 7a) compared with the control. Obvious body weight loss was observed after treatment with DHQ3 and 17-DR (Fig. 7b). When each animal was considered individually, the incidence of 


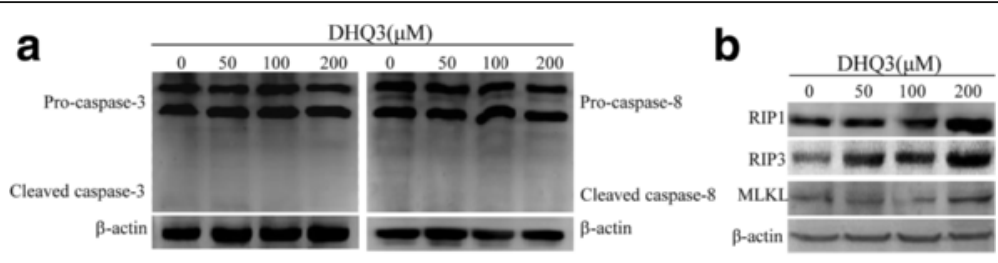

C

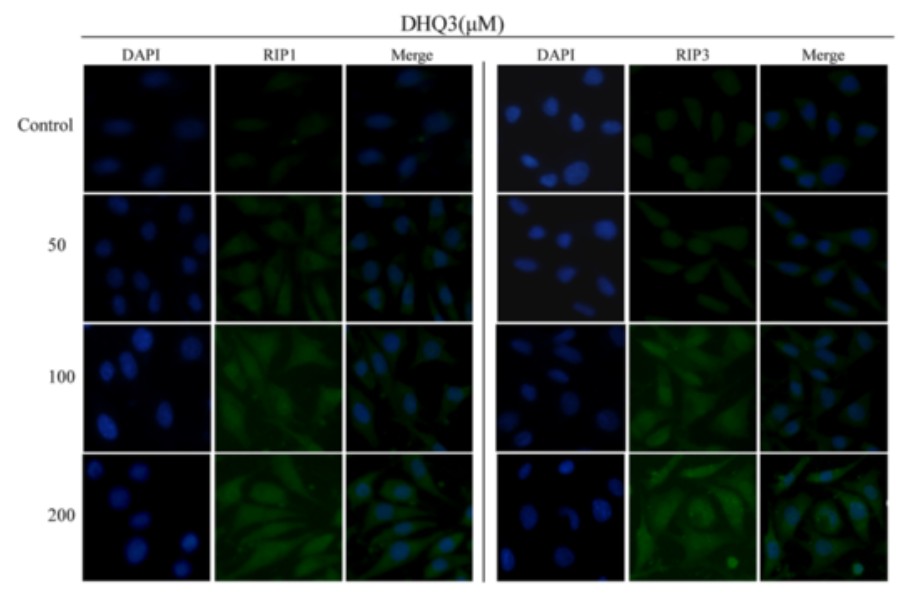

d
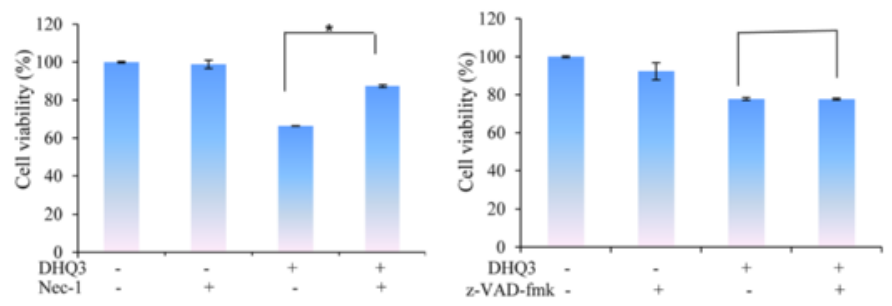

e

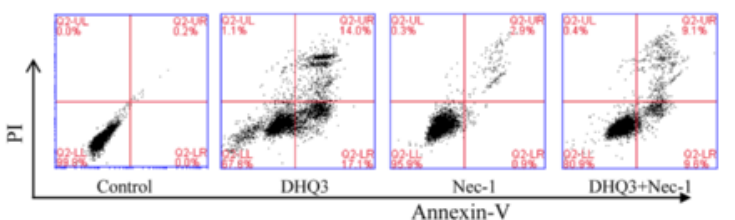

Fig. $4 \mathrm{DHQ} 3$ induced necroptosis in MDA-MB-231 cells. a Cells were treated with DHQ3 for $24 \mathrm{~h}$. Cell lysates were prepared and examined using western blot analysis. $\mathbf{b}$ The expression of necroptosis-related proteins was analyzed by western blot. c MDA-MB-231 cells were incubated with $\mathrm{DHQ} 3$ for $24 \mathrm{~h}$ and treated with primary antibodies overnight at $4{ }^{\circ} \mathrm{C}$. The localization of the target proteins was assessed by immunofluorescence staining. Nuclei were stained with DAPI. Scale bar is $50 \mu \mathrm{m}$. d Cells incubated with DHQ3 $(200 \mu \mathrm{M})$ for $24 \mathrm{~h}$, with or without $1 \mathrm{~h}$ pre-treatment

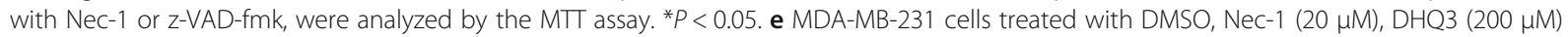
alone or with Nec-1 pre-treatment, were analyzed by Annexin V-FITC/PI assay

mice progressing with a tumor volume of $500 \mathrm{~mm}^{3}$ was significantly diminished by day 15 in DHQ3/17DR-treated animals compared with controls (Fig. 7c). Consistent with body weight data, 17-DR- or DHQ3treated groups exhibited obvious decrease in tumor weight (Fig. 7d). Aspartate aminotransferase (AST) and alanine-aminotransferase (ALT) are commonly used as biomarkers for the evaluation of hepatotoxicity [31], after the treatment of 17-DR or DHQ3, the levels of AST and ALT were analyzed using an activity assays, showing that 17-DR and DHQ3 had nearly no effect on the AST and ALT compared with those of the control group, but obviously lower than those of the DDP-treated group (Fig. 7e). H\&E staining of the organs such as the liver, lung and kidney demonstrate that there was no serious damage (Fig. 7f). All of the results provided evidence for its antitumorigenic action with low hepatotoxicity in vivo.

\section{DHQ3 and 17-DR do not induce different forms of death in other cancer cell lines}

Based on these interesting data, a series of cancer cell lines were treated with the same concentrations of DHQ3 or 17-DR, as well as pre-treated with Nec-1, as in 

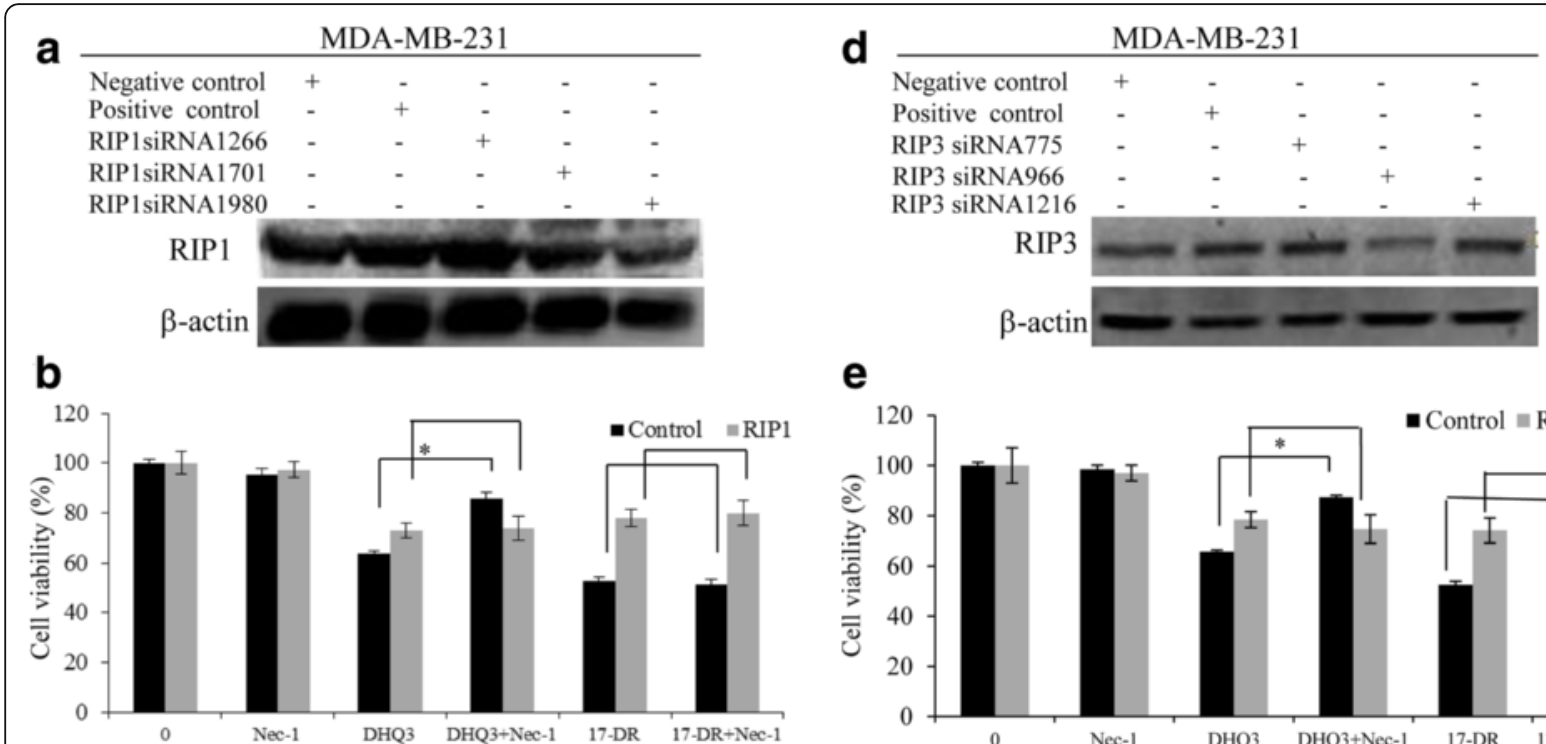

e

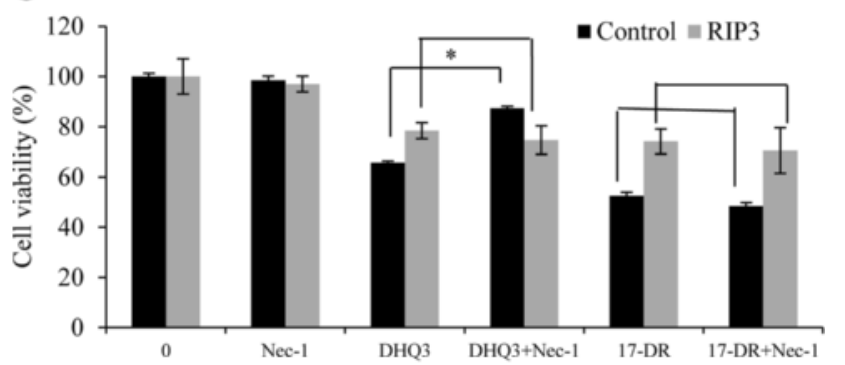

C

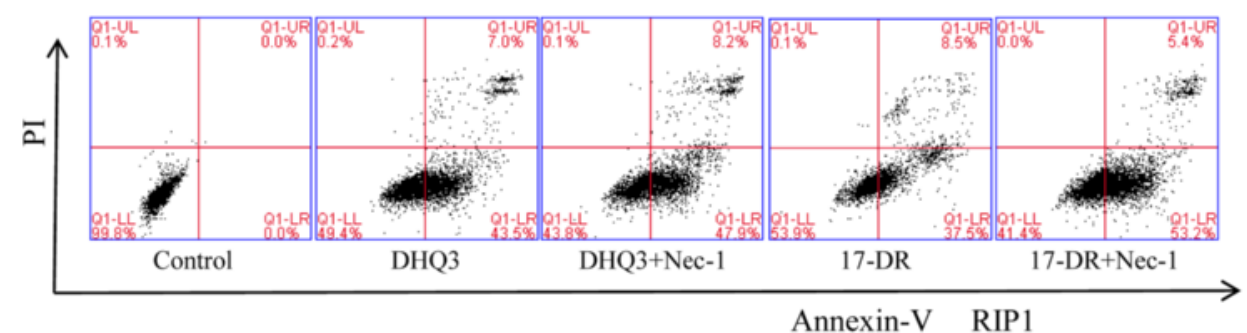

f

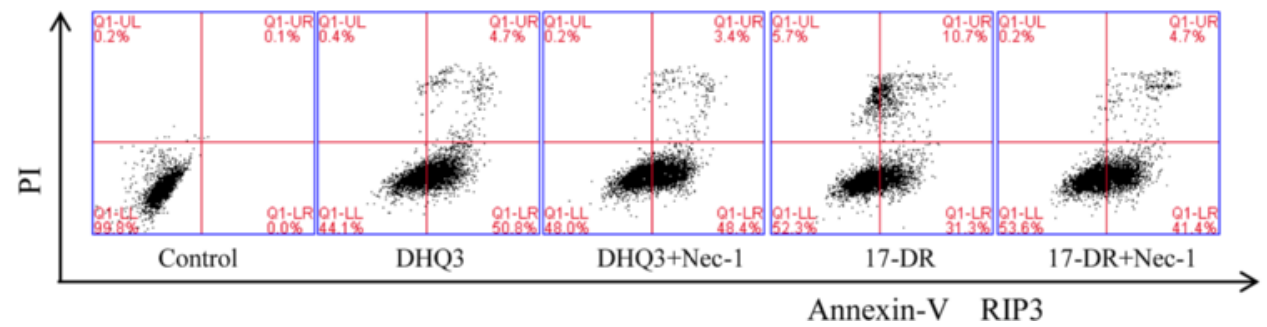

Fig. 5 Knockdown of RIPs with siRNA protected against DHQ3-induced necroptosis in MDA-MB-231 cells. a, d MDA-MB-231 cells were transfected with control, or RIP1 or RIP3 siRNA, and after $48 \mathrm{~h}$, whole-cell lysates were subjected to western blot analysis. $\mathbf{b}$, e After $24 \mathrm{~h}$ transfection with RIP1/RIP3 siRNA, cells were treated with $200 \mu \mathrm{M}$ of analogs for another $24 \mathrm{~h}$, with or without $1 \mathrm{~h}$ pre-treatment with Nec-1 and z-VAD-fmk. Cell viability was measured by MTT assay. ${ }^{*} P<0.05$. c, f Similarly to b, MDA-MB-231 cells were analyzed by Annexin V-FITC/PI assay

the experiments with MDA-MB-231 cells (Fig. 8). Under the conditions used, the same phenomenon of different forms of cell death with different analogs was not observed in these other cancer cell lines. Remarkably, combined with Nec-1 rescued MCF-7, MDA-MB-231, T-47D cells to DHQ3. However, Nec-1 did not rescue HepG2, SMMC7721, CNE-2Z, HNE1, A549, SGC7901, ISK and SW480 cells from DHQ3-induced cell death at all.

\section{Discussion}

The MDA-MB-231 cell line is a type of triple-negative breast cancers (TNBC), which has been tested negative for estrogen receptors, progesterone receptors and
HER2 [32]. Relatively few drugs work against TNBC, and there is a lack of standardized medication guidelines for TNBC. The expression of Hsp90 in tumor cells is 210 times higher than in normal cells, therefore, Hsp90 inhibitors could show selectivity towards tumor cells, yielding specific antitumor effects [7, 33]. In study, DHQ3 and 17-DR presented potent antitumor activity for TNBC in vitro and in vivo.

On the basis of the strong ties between Hsp90 and carcinogenesis, a significant proportion of the work on Hsp90 inhibitors have been committed to developing derivatives of GA, including 17-AAG and 17ABAG [34-37]. However, there seems to be a limit to 
a
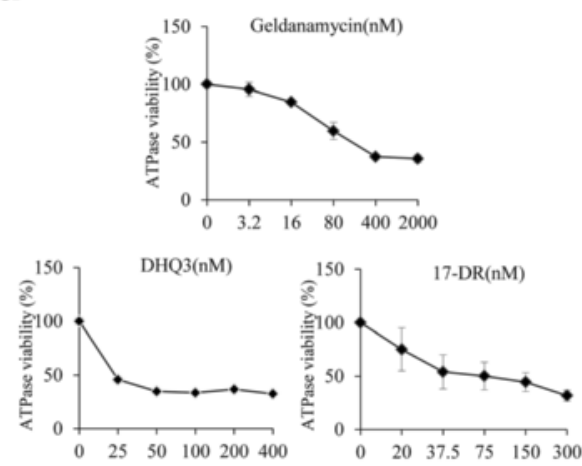

C

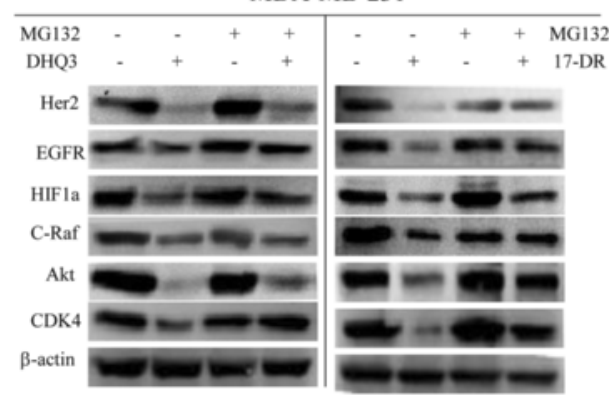

b
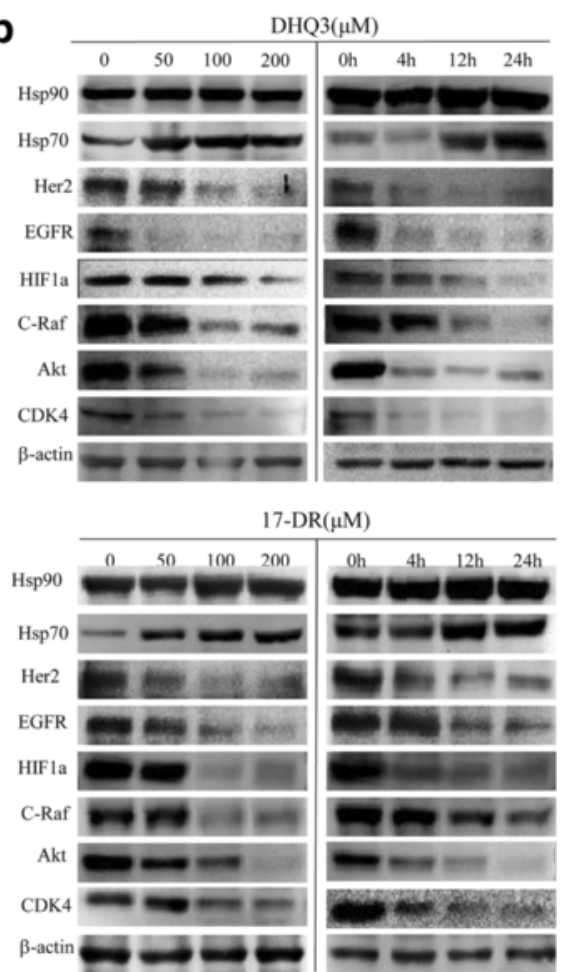

Fig. $6 \mathrm{DHQ3}$ and 17-DR induced the degradation of Hsp90 client proteins. a Hsp90 ATPase activity at different concentrations of GA, DHQ3 and 17-DR were tested by the malachite green-phosphate and ammonium molybdate method. At the given times, the reaction was stopped and the $\mathrm{OD}_{650}$ value measured. $\mathbf{b}$ Cells were treated with analogs at different concentrations or different lengths of time, the Hsp90 client proteins were

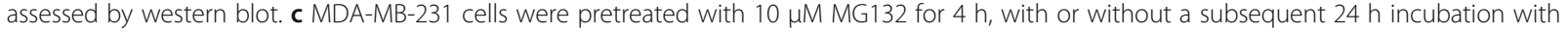
$200 \mu \mathrm{M}$ DHQ3 or $200 \mu \mathrm{M}$ 17-DR. Whole-cell lysates were subjected to western blot analysis

further development of most of these inhibitors. Therefore, there is a need for further analysis of analogs. Our findings indicated that the new nonquinone GA analogs DHQ3 and 17-DR have high activity against a series of cancer cells, especially MDAMB-231 cells. As Hsp90 inhibitors, they were tested for the ability to inhibit yeast Hsp90 activity using a malachite green ATPase assay, and displayed stronger inhibition of ATPase activity than GA. Furthermore, down-regulated the levels of Hsp90 client proteins, and the degradations of these client proteins were blocked by treatment with the proteasome inhibitor MG132. More importantly, the result of this study showed that DHQ3 and 17-DR have potent inhibitory effects on MDA-MB-231 breast cancer cell tumor growth, and showed low hepatotoxicity in vivo and no serious side effects.

Interestingly, DHQ3-induced necroptosis is dependent on RIP1 and RIP3, a classical mode of necroptosis, while 17-DR-treated cells display the characteristic changes of apoptosis. We found that 17-DR regulates apoptosisrelated proteins, and that it induces apoptosis of MDAMB-231 cells in a caspase-3, -8 dependent manner. Our data also demonstrated that treatment with DHQ3 resulted in significant induction of necroptosis associated with expression of RIP. Recent research has underlined RIP3 as a key protein regulating the switch between TNF-induced necroptosis and survival, and indicated that the complex containing RIP3 could function as a "necrosome" which differ from other complexes that induce apoptosis or NF-kB activation [17, 18, 38]. The state of RIP determines whether it functions as a molecule that promotes or inhibits cell death [39]. Our work showed that DHQ3 treatment markedly increased the level of RIP1 and RIP3 in MDA-MB-231.

It is puzzling that the two analogs with similar structure would guide MDA-MB-231 cells towards two different cell death programs. In our siRNA studies, we clearly demonstrated the importance of RIP1 and RIP3 in the death process. The data indicate that knockdown of RIP1 and RIP3 expression inhibit DHQ3-induced necroptosis, and cause the loss of protective effect of Nec-1, but has no effect on 17-DR-induced apoptosis. Furthermore, it has been revealed that GA accelerates the molecular switch from necroptosis to apoptosis via RIP1 down-regulation in TNF-stimulated L929 cells [40]. As described above, RIP is one of the client protein of Hsp90, therefore we hypothesize that the two Hsp90 

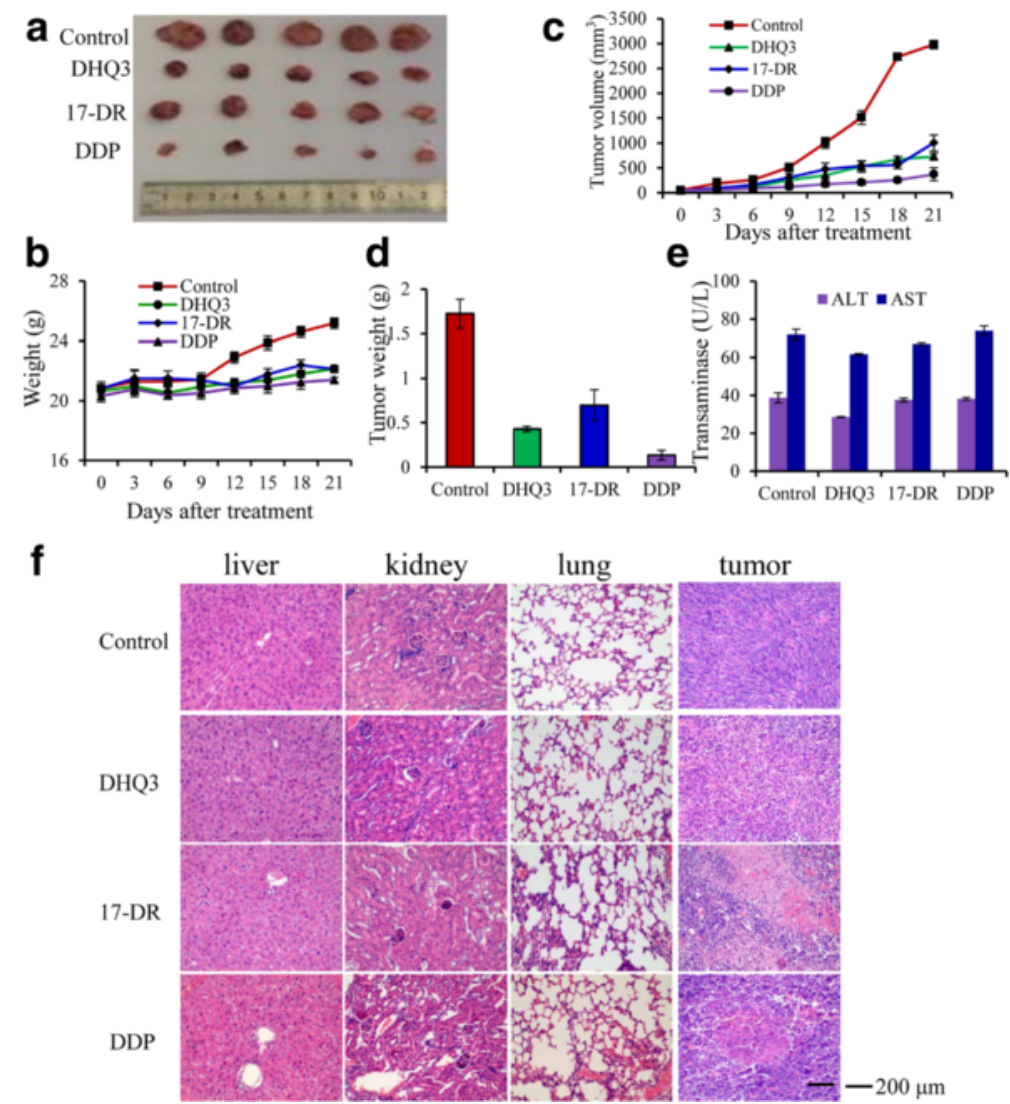

Fig. $7 \mathrm{DHQ} 3$ and 17-DR significantly delays MDA-MB-231 tumor growth. a Representative tumors from each treatment group. b Body weight of the mice. c Tumor volume of the mice. $\mathbf{d}$ Tumor weights after DHQ3, 17-DR and DDP treatment. e In vivo hepatotoxicity evaluation of DHQ3 and 17-DR in nude mice. The AST and ALT were determined by Assay Kit. The blood serum samples were treated according to the manufacturer's instruction. And the AST and ALT activities are expressed as U/L. $\mathbf{f} H \& E$-stained sections of the tumor, liver, lung and kidney from the mice after treatment

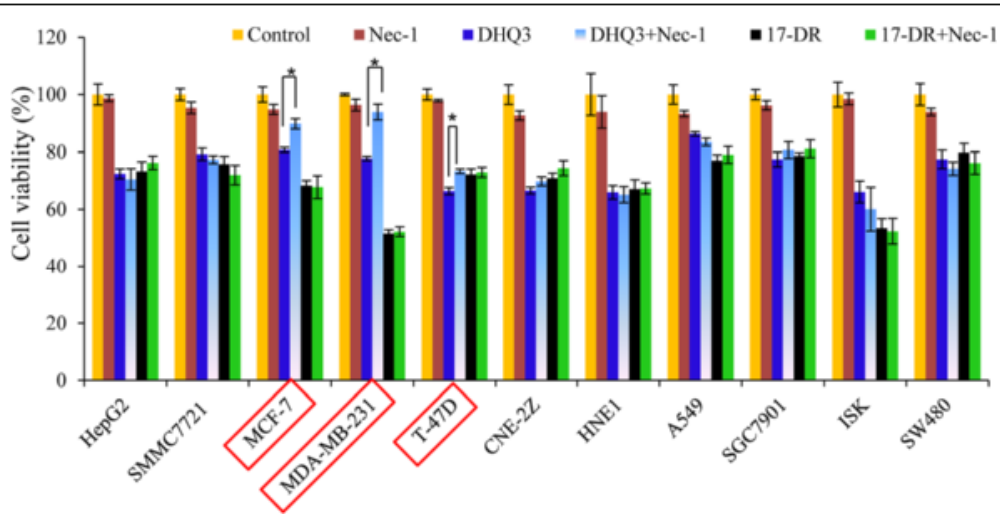

Fig. 8 MTT results of DHQ3 and 17-DR on ten human cancer cell lines. HepG2, SMMC7721, MCF-7, MDA-MB-231, T-47D,CNE-2Z, HNE1, A549, SGC7901, ISK, SW480 were exposed to $200 \mu \mathrm{M}$ analogs as in previous experiments with MDA-MB-231 cells for $24 \mathrm{~h}$, with or without pre-treatment with Nec-1. The cell survival rates were assessed using MTT assays. ${ }^{*} P<0.05$ 
inhibitors induce different forms of death by having slightly different effects on RIP. This is of importance and merits further investigation. Further, in-depth testing is required to determine the efficacy.

\section{Conclusions}

In summary, the two new non-benzoquinone GA analogs, DHQ3 and 17-DR, inhibited the proliferation of MDA-MB-231 cells by decreasing the expression of Hsp90 client proteins. They have potent inhibitory effects on MDA-MB-231 breast cancer cell tumor growth with low hepatotoxicity. Importantly, our observations revealed that they triggered different forms of death in MDA-MB-231 cells. DHQ3 functions as an Hsp90 inhibitor and a necroptosis inducer, while 17-DR induces caspase-dependent apoptosis.

\section{Abbreviations \\ 17-DR: 17-demethoxy-reblastatin; Akt: Serine/threonine kinase; ALT: Alanine- aminotransferase; AST: Aspartate aminotransferase; BSA: Bovine serum albumin; CDK4: Cyclin dependent kinase 4; C-Raf: Raf proto-oncogene serine/threonine- protein kinase; DAPI: 4,6-diamidino-2-phenylindole; DMEM: Dulbecco's modified Eagle's medium; DMSO: Dimethyl sulfoxide; EGFR: Epidermal growth factor receptor; FBS: Fetal bovine serum; GA: Geldanamycin; HCC: Human hepatocellular carcinoma; Her2: Human epidermal growth factor receptor 2; HIF1a: Hypoxia- inducible factor; HSPs: Heat shock proteins; MLKL: Mixed lineage kinase domain- like protein; MTT: 3-(4,5-Dimethylthiazol-2-yl)-2,5-diphenyltetrazolium bromide; Nec-1: Necrostatin-1; PBS: Phosphate-buffered saline; PI: Propidium iodide; PVDF: Polyvinylidene fluoride; RIP: Receptor-interacting protein; RPMI-1640: Roswell park memorial institute-1640 medium; SDS-PAGE: Sodium dodecyl sulfate- polyacrylamide gel electrophoresis; TNBC: Triple-negative breast cancers}

\section{Acknowledgements}

This work was supported by the National Science Foundation of China (No. $81372899,81302671)$, the Natural Science Foundation of the Anhui Province (1508085MH166, 1408085QH162), Education Department of Anhui Natural Science Research Project China (KJ2016SD39, KJ2016A465), Internationa scientific and technological cooperation projects in Anhui Province (No.1503062024), the Foundation of Bengbu Medical College (No. Byycxz1516).

\section{Funding}

Not applicable.

\section{Availability of data and materials}

Please contact author for data requests.

\section{Authors' contributions}

Conceived and designed the experiments: HL, C-ZW. Performed the experiments: ZZR, LHM, ZC. Analyzed the data: LQX, MLY, SYM, ZB. Wrote and proofread the paper: ZZR. Revision of the manuscript: WLR, ZXD. Provide the analogs: Young-Soo Hong, WCZ. All authors read and approved the final manuscript.

\section{Competing interests}

The authors declare that they have no competing interests.

\section{Consent for publication}

Not applicable.

\section{Ethics approval and consent to participate}

All procedures performed in studies involving nude mice were in accordance with the ethical standards of the Bengbu Medicine College committee.

\section{Author details}

${ }^{1}$ Faculty of Pharmacy, Bengbu Medical College, Bengbu 233000, Anhui, People's Republic of China. ${ }^{2}$ Department of Clinical medicine, Bengbu Medical College, Bengbu 233000, Anhui, People's Republic of China.

${ }^{3}$ Department of Pharmaceutical Sciences, School of Pharmacy, Computational Chemical Genomics Screening Center, Pittsburgh, PA, USA.

${ }^{4}$ School of Medicine and Public Health, University of Newcastle, Newcastle, NSW, Australia. ${ }^{5}$ Department of Gastrointestinal Surgery, The first Affiliated Hospital of Bengbu Medical College, Bengbu 233000, Anhui, People's Republic of China. ${ }^{6}$ Chemical Biology Research Center, KRIBB, Cheongju 28116, Republic of Korea.

Received: 6 July 2016 Accepted: 14 September 2016 Published online: 22 September 2016

References

1. Ferlay J, Soerjomataram I, Dikshit R, Eser S, Mathers C, Rebelo M, Parkin DM, Forman D, Bray F. Cancer incidence and mortality worldwide: sources, methods and major patterns in GLOBOCAN 2012. Int J Cancer. 2015;136(5): E359-86.

2. Xing H, Weng D, Chen G, Tao W, Zhu T, Yang X, Meng L, Wang S, Lu Y, Ma D. Activation of fibronectin/PI-3K/Akt2 leads to chemoresistance to docetaxel by regulating survivin protein expression in ovarian and breast cancer cells. Cancer Lett. 2008:261(1):108-19.

3. Maloney A, Workman P. HSP90 as a new therapeutic target for cancer therapy: the story unfolds. Expert Opin Biol Ther. 2002;2(1):3-24.

4. Whitesell L, Santagata S, Mendillo ML, Lin NU, Proia DA, Lindquist S. HSP90 empowers evolution of resistance to hormonal therapy in human breast cancer models. Proc Natl Acad Sci U S A. 2014;111(51):18297-302.

5. Li D, Xu T, Cao Y, Wang H, Li L, Chen S, Wang X, Shen Z. A cytosolic heat shock protein 90 and cochaperone CDC37 complex is required for RIP3 activation during necroptosis. Proc Natl Acad Sci U S A. 2015;112(16):5017-22.

6. Trepel J, Mollapour M, Giaccone G, Neckers L. Targeting the dynamic HSP90 complex in cancer. Nat Rev Cancer. 2010;10(8):537-49.

7. Neckers L, Neckers K. Heat-shock protein 90 inhibitors as novel cancer chemotherapeutic agents. Expert Opin Emerg Drugs. 2002;7(2):277-88.

8. Wu CZ, Moon AN, Jang JH, Lee D, Kang SY, Park JT, Ahn JS, Hwang BY, Kim YH, Lee HS, Hong YS. New non-quinone geldanamycin analogs from genetically engineered Streptomyces hygroscopicus. J Antibiot (Tokyo). 2011;64(6):461-3.

9. Shin JC, Na Z, Lee DH, Kim WC, Lee K, Shen YM, Paik SG, Hong YS, Lee JJ. Characterization of tailoring genes involved in the modification of geldanamycin polyketide in Streptomyces hygroscopicus JCM4427. J Microbiol Biotechnol. 2008;18(6):1101-8.

10. Zhao Q, Wu CZ, Lee JK, Zhao SR, Li HM, Huo Q, Ma T, Zhang J, Hong YS, Liu H. Anticancer effects of the Hsp90 inhibitor 17-demethoxy-reblastatin in human breast cancer MDA-MB-231 cells. J Microbiol Biotechnol. 2014;24(7):914-20.

11. Zhao S, Li H, Jiang C, Ma T, Wu C, Huo Q, Liu H. 17-Demethoxy-reblastatin, an Hsp90 inhibitor, induces mitochondria-mediated apoptosis through downregulation of $\mathrm{Mcl}-1$ in human hepatocellular carcinoma cells. J Bioenerg Biomembr. 2015;47(5):373-81.

12. Green DRL, Llambi F. Cell death signaling. Cold Spring Harb Perspect Biol. 2015;7(12):a006080.

13. Lheureux S, Le Moulec S. Molecules involved in apoptosis regulation as therapeutic targets in oncology. Bull Cancer. 2011;98(9):1029-36.

14. Degterev A, Huang Z, Boyce M, Li Y, Jagtap P, Mizushima N, Cuny GD, Mitchison TJ, Moskowitz MA, Yuan J. Chemical inhibitor of nonapoptotic cell death with therapeutic potential for ischemic brain injury. Nat Chem Biol. 2005;1(2):112-9.

15. de Almagro MC, Vucic D. Necroptosis: pathway diversity and characteristics. Semin Cell Dev Biol. 2015;39:56-62.

16. Zhou W, Yuan J. Necroptosis in health and diseases. Semin Cell Dev Biol. 2014;35:14-23.

17. Declercq W, Vanden Berghe T, Vandenabeele P. RIP kinases at the crossroads of cell death and survival. Cell. 2009;138(2):229-32

18. Zhang DW, Shao J, Lin J, Zhang N, Lu BJ, Lin SC, Dong MQ, Han J. RIP3, an energy metabolism regulator that switches TNF-induced cell death from apoptosis to necrosis. Science. 2009;325(5938):332-6.

19. Sun L, Wang H, Wang Z, He S, Chen S, Liao D, Wang L, Yan J, Liu W, Lei X, Wang X. Mixed lineage kinase domain-like protein mediates necrosis signaling downstream of RIP3 kinase. Cell. 2012;148(1-2):213-27. 
20. Cho YS, Challa S, Moquin D, Genga R, Ray TD, Guildford M, Chan FK. Phosphorylation-driven assembly of the RIP1-RIP3 complex regulates programmed necrosis and virus-induced inflammation. Cell. 2009;137(6): 1112-23.

21. Degterev A, Hitomi J, Germscheid M, Ch'en IL, Korkina O, Teng X, Abbott D, Cuny GD, Yuan C, Wagner G, Hedrick SM, Gerber SA, Lugovskoy A, Yuan J. Identification of RIP1 kinase as a specific cellular target of necrostatins. Nat Chem Biol. 2008:4(5):313-21.

22. Zhao J, Jitkaew S, Cai Z, Choksi S, Li Q, Luo J, Liu ZG. Mixed lineage kinase domain-like is a key receptor interacting protein 3 downstream component of TNF-induced necrosis. Proc Natl Acad Sci U S A. 2012;109(14):5322-7.

23. Zhang T, Zhang Y, Cui M, Jin L, Wang Y, Lv F, Liu Y, Zheng W, Shang H, Zhang J, Zhang M, Wu H, Guo J, Zhang X, Hu X, Cao CM, Xiao RP. CaMKII is a RIP3 substrate mediating ischemia- and oxidative stress-induced myocardial necroptosis. Nat Med. 2016:22(2):175-82.

24. Avila C, Hadden MK, Ma Z, Kornilayev BA, Ye QZ, Blagg BS. High-throughput screening for Hsp90 ATPase inhibitors. Bioorg Med Chem Lett. 2006;16(11): 3005-8.

25. Chang L, Bertelsen EB, Wisen S, Larsen EM, Zuiderweg ER, Gestwicki JE. Highthroughput screen for small molecules that modulate the ATPase activity of the molecular chaperone DnaK. Anal Biochem. 2008;372(2):167-76.

26. Blagosklonny MV. Hsp-90-associated oncoproteins: multiple targets of geldanamycin and its analogs. Leukemia. 2002;16(4):455-62.

27. Schulte TW, Blagosklonny MV, Romanova L, Mushinski JF, Monia BP, Johnston JF, Nguyen P, Trepel J, Neckers LM. Destabilization of Raf-1 by geldanamycin leads to disruption of the Raf-1-MEK-mitogen-activated protein kinase signalling pathway. Mol Cell Biol. 1996;16(10):5839-45.

28. Demidenko ZN, An WG, Lee JT, Romanova LY, McCubrey JA, Blagosklonny MV. Kinase-addiction and bi-phasic sensitivity-resistance of Bcr-Abl- and Raf-1expressing cells to imatinib and geldanamycin. Cancer Biol Ther. 2005;4(4):484-90.

29. Blagosklonny MV, Fojo T, Bhalla KN, Kim JS, Trepel JB, Figg WD, Rivera Y, Neckers LM. The Hsp90 inhibitor geldanamycin selectively sensitizes Bcr-Ablexpressing leukemia cells to cytotoxic chemotherapy. Leukemia. 2001;15(10): 1537-43.

30. Sidera K, Patsavoudi E. HSP90 inhibitors: current development and potential in cancer therapy. Recent Pat Anticancer Drug Discov. 2014;9(1):1-20.

31. Llanos L, Moreu R, Ortin T, Peiro AM, Pascual S, Bellot P, Barquero C, Frances R, Such J, Perez-Mateo M, Horga JF, Zapater P. The existence of a relationship between increased serum alanine aminotransferase levels detected in premarketing clinical trials and postmarketing published hepatotoxicity case reports. Aliment Pharmacol Ther. 2010;31(12):1337-45.

32. Arnedos M, Bihan C, Delaloge S, Andre F. Triple-negative breast cancer: are we making headway at least? Ther Adv Med Oncol. 2012;4(4):195-210.

33. Kamal A, Thao L, Sensintaffar J, Zhang L, Boehm MF, Fritz LC, Burrows FJ. A high-affinity conformation of Hsp90 confers tumour selectivity on Hsp90 inhibitors. Nature. 2003;425(6956):407-10.

34. Sharp S, Workman P. Inhibitors of the HSP90 molecular chaperone: current status. Adv Cancer Res. 2006;95:323-48.

35. Lin Z, Peng R, Li Z, Wang Y, Lu C, Shen Y, Wang J, Shi G. 17-ABAG, a novel geldanamycin derivative, inhibits LNCaP-cell proliferation through heat shock protein 90 inhibition. Int J Mol Med. 2015;36(2):424-32.

36. Wang J, Li Z, Lin Z, Zhao B, Wang Y, Peng R, Wang M, Lu C, Shi G, Shen Y. 17-DMCHAG, a new geldanamycin derivative, inhibits prostate cancer cells through Hsp90 inhibition and survivin downregulation. Cancer Lett. 2015; 362(1):83-96.

37. Ramanathan RK, Trump DL, Eiseman JL, Belani CP, Agarwala SS, Zuhowski EG, Lan J, Potter DM, Ivy SP, Ramalingam S, Brufsky AM, Wong MK, Tutchko S, Egorin MJ. Phase I pharmacokinetic-pharmacodynamic study of 17(allylamino)-17-demethoxygeldanamycin (17AAG, NSC 330507), a novel inhibitor of heat shock protein 90, in patients with refractory advanced cancers. Clin Cancer Res. 2005;11(9):3385-91.

38. Humphries F, Yang S, Wang B, Moynagh PN. RIP kinases: key decision makers in cell death and innate immunity. Cell Death Differ. 2015;22(2):225-36.

39. Silke J, Rickard JA, Gerlic M. The diverse role of RIP kinases in necroptosis and inflammation. Nat Immunol. 2015;16(7):689-97.

40. Vercammen D, Vandenabeele P, Beyaert R, Declercq W, Fiers W. Tumour necrosis factor-induced necrosis versus anti-Fas-induced apoptosis in L929 cells. Cytokine. 1997;9(11):801-8.

\section{Submit your next manuscript to BioMed Central and we will help you at every step:}

- We accept pre-submission inquiries

- Our selector tool helps you to find the most relevant journal

- We provide round the clock customer support

- Convenient online submission

- Thorough peer review

- Inclusion in PubMed and all major indexing services

- Maximum visibility for your research

Submit your manuscript at www.biomedcentral.com/submit
( Biomed Central 